\title{
Social Realism and Psychological Transformation of Women Protagonist in Nayantara Sahgal's Storm in Chandigarh and a Situation in New Delhi - A Study
}

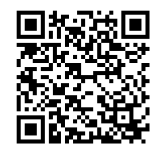

\author{
G Sankar $^{1 *}$, L Kamaraj ${ }^{2}$ and A Mohamed Ansath Raja ${ }^{3}$ \\ ${ }^{1}$ Department of English, PSG College of Technology, India \\ ${ }^{2}$ Department of English, KSK College of Education, India \\ ${ }^{3}$ Department of English, DMI College of Engineering, India
}

Submission: January 27, 2018; Published: March 13, 2018

*Corresponding author: G Sankar, Department of English, PSG College of Technology, Coimbatore-641004, India, Email: sankarliterature@gmail.com

\begin{abstract}
The Research paper aims to focus on Nayantara Sahgal's position in it as a novelist. It also discusses in detail a critical study of the social realism and Psychological Transformation with survival strategies of the woman protagonist in Nayantara Sahgal's Storm in Chandigarh and A Situation in New Delhi. How Nayanara Sahgal's writing was different from other Indian writers. During almost six decades of post-colonial history of Indian English fiction, a wide variety of novelists have emerged focusing attention on a multitude of social, economic, political, religious and spiritual issues faced by three conceding periods of human experience. With the turn of the century the Indian English novelists have surpassed their male counterparts outnumbering hem quantitatively as well as maintaining a high standard of literary writing, equally applauded in India and abroad, experimenting boldly with not only technique but also incorporating tabooed subject matters in their novels and short stories.
\end{abstract}

keywords: Social-realism; Psychological transformation; Survival strategies; women protagonist

\section{Introduction}

Nayantara Segal was born in a family of freedom fighters, which had politics in its very blood; Sahgal has indeed written political novels of high quality. Authors like Kamala Markandaya, Shashi Deshpande and Anita Desai have chosen the problems and issues faced by the women in today's male dominated world as the main theme of their works. For instance, some of the novels of Anita Desai like, Voices in the City and Where Shall We Go This Summer? Have portrayed the complexities of man and woman relationship. She has tried to explore the psychological aspects of the lead protagonists. The women novelists try to create an awareness to bring about a social change. The novels of Nayantara Sahgal foreground her as a writer with feminist concerns seeking independent existence of women. She sees women as victims of conventional Indian society struggling in their quest for identity. She has a political background and it helps considerately her political news. She is also different from the feminist novelist because most of these writers speak about feminism in a domestic way. But Nayanara Sahgal perspective is a political views. She is the only woman to outspokenly and boldly write about politics [1].

Nayantara Sahgal could also be considered as a woman novelist: In almost every novel, Nayantara has a central woman character, who gradually moves towards an awareness of her emotional needs. The emotional world of woman is explored and analyzed with admirable insight and sympathetic perception. Her concern for the women who are caught in the dilemma of liberty and individuality or stability and protection of marriage is understandable. She has shown tremendous understanding of the problems and the predicaments of the women she has exploited her skill in projecting convincingly the agonized mind of the persecuted women. Her portrayal of women characters in the novels invariably bears authenticity to their feminist approach, outlook and perspective. Her keen observation of the life of Indian women and their interest in the study of their inner mind are evidenced by their vivid and panoramic portrayal of their plight.

\section{Values and Attitudes}

Nayantara Sahgal's childhood and adolescence were spent amidst India's political reverberations, the crusade for emancipation from the British yoke and the influence of Gandhian ideas of freedom and non-violence. She has, as A.V. Krishna Rao states, "inherited and cherished a certain set of values and attitudes toward life which can be best described as a complex of political liberalism, social sophistication, economic 
moderation and cultural catholicity in continual interaction with the Gandhian idealism [2]."

Nayantara Sahgal has a central woman character who gradually moves towards an awareness of her emotional needs. Nayantara Sahgal's novel reads like commentaries on the political and social turmoil that India has been facing since independence. Mrs. Sahgal's feelings for politics and her command over English are rather more impressive than her art as a novelist. She is a novelist as well as a successful political columnist for different newspapers. Her writing is generally characterized by simplicity and boldness. Her writing abounds the latest political ups and downs with a tinge of western liberalism. Her novels portray the contemporary incidents and political realities saturated with artistic and objectivity. All her major characters of the novel are drawn towards the vortex of politics [3].

Besides politics, her fiction also focuses attention on Indian woman's search for sexual freedom and self-realization. As a women novelist, Sahgal recognizes that her primary obligation is that of advocating the emancipation of women. She has probed deep into the female psyche in her novels. She describes in her novel how women's exploited even during the modern times by both the individuals and the society. She tried to Portray the sensibility of woman that how a woman looks at herself and her problems [4].

She considers her novels political in content and intention and in her view, each of the novels more or less her contemporary reflects and political era. The use of the fictional genre is one of the main aspects of her novels, wherein she can explore the problems of women in contemporary society. Though Sahgal has been hailed chiefly as a political novelist, her feminist concern is obvious and her fighter spirit quite vocal in her fiction. In all her works, there is juxtaposition of two worlds: the personal world of man-woman relationship and the impersonal world of politics. The portrayal of her memorable women characters and the feminist tone in her fictional discourse make Nayantara Sahgal one of the most outstanding feminist Indian novelists writing in English [5].

Nayantara Sahgal is not only a novelist of repute but also a journalist by profession. She confesses that fiction is her "abiding love" journalism her "conscience". Talking to Ram Jha in 1987, Sahgal said that her two kinds of writing experiences-that of a novelist and that of a political journalist-though contrary to each other, are mutually sustained because, her central focus in both areas in the same-the concept of freedom in human beings, national and personal and her increasingly feminist concerns.

Most of her characters belong to the affluent upper class, she does not caste-ridden middle class or the poor Indian village just to conform to the accepted image of India. Her range of characters simplifies her technique. She does not have to struggle to present Indian conversation in English as most of her characters are the kind of people who would talk and think in English in real life [6].
Sahgal has first-hand knowledge of political figures in India, for she spent most of her childhood in Anand Bhawan the ancestral home of the Nehru's in Allahabad. One could say that politics is in her blood-Jawaharlal Nehru was her mother's rather, while her father died because of illness he suffered in prison when he was jailed for participating in India's freedom struggle. An important political event forms the background for each of her novels [7].

Storm in Chandigarh is Mrs. Sahgal's third novel written after A Time to be Happy and This Time of Morning. It deals with complex human relationships in which love, friendship, honesty, freedom and equality play a vital role. The 'Storm' in the lives of three married couples, Inder and Saroj, Jit and Mara, Vishal and Leela is portrayed against the political backdrop of the storm or confrontation between the newly divided states of Punjab and Haryana over the issues of Chandigarh and Bakhra Nangal territory act...Gyan Singh, the ambitious Chief Minister of Punjab has announced a strike in the whole region for the selfish purpose of demonstrating his political strength. He is only concerned with his personal gains and does not even hesitate to use violence as a means for achieving his selfish ends. While Harpal Singh, the Chief Minister of Haryana acts as political counter oil of Gyan Singh as he is a behavior of Gandhi an ideology of non-violence. He has always given priority to the interests of people against his self-interest. The union Home Minister is assigned the task of affecting a rapprochement between the two warring states of Vishal Dubey, an honest and promising central officer. Dubey goes to Chandigarh from Delhi to solve the political impasse but unwillingly involves himself in the private lives of the estranged husbands and wives especially those of Saroj and Inder $[8,9]$.

\section{Socio-Political Consciousness}

Storm in Chandigarh has five major characters and the personal and the political worlds run parallel to each other. The political atmosphere instead of improving seems to have deteriorated. The people who have some values or ideals are inert and passive and unable to face reality. Those who are active and aggressive have no values, they have no scruples. The building of Chandigarh symbolized a new beginning. Vishal Dubey finds himself amidst a political confrontation in Chandigarh where Gyan Singh is trying to link up the issues if language to religion to exploit religious sentiments for his own interests.

His instigation is a threat to the peace and normalcy of life but no one is willing to take a stand against it. Dubey is unable to understand the reason for the violence and attitude. Violence was a political blackmail. It had yielded dividends in the past and was again being used a threat. Violence, Dubey feels is the joint product of the aggressive and the inert; it was a sign of urban discontents. Out bursts of brutal, calculated violence had become a part of the cities. The situation in Chandigarh is not one of tension but of paralysis, the situation in which one felt trapped and helpless. The political dead lock in Chandigarh is a reflection of the state of affairs in other parts of the country. The 
watch word of the government is with Dubey "wait and watch". People are afraid to accept the challenges, afraid to act or think. Dubey is conscious of the change even in the basic approach to life and its problems.

In this novel the novelist focuses attention on this national ailment. She presents the reality of the political situation in the late sixties She is successful in capturing not only the political issues but also the political mood and intrigues. She has also touched upon the deterioration that had set in the quality of public life and which was bound to influence personal and private values.

Nayantara Sahgal touches tradition and modernity in terms of ethics and morality. Ethics and morality have been given distinct identities and meaning by the modern educated people like Trivedi and Vishal Dubey. For instance, Debey would not subscribe to what is commonly understood as morality. Trivedi's suggestion that Dubey might believe in free love, he declares that he does not accept the established ideas and about morality.

Sahgal's Storm in Chandigarh deals with the problem of political tension and violence originating from its being Chandigarh, the common capital of the two states-the Punjab and Haryana. The novel depicts violence, chaos and the uneasy political situation of late sixties of the partition of the Punjab into two newly formed states Punjabi-speaking Punjab and Hindispeaking Haryana with Chandigarh as the common capital. The novel deals with the political upheaval in Punjab in the postindependence period. Beside the political background, there is also a human background which has not received adequate treatment. The fictional situation of young hearts broken by compulsions of marriage and call of new love suggests that marriage is not just sexual relationship; it means companionship on equal terms. The cause of disturbance in the relations between man and woman partly lies in man's own inherent debility to indulge in adultery in the unnatural position of the husband or the wife in the family. Women characters in the novel do not like to remain confined within the four walls of their houses. They prefer to go picnic to relieve the burden of boredom and monotony. The clash between Gyan Singh and Harpal Singh is a clash of ideologies. It is a fight between the cults of violence versus the idea of non-violence. Gyan who shows little concern for emotions and human beings always is ruthless. Harpal on the other hands more concerned with human beings than with anything else, each time there is a confrontation between the two Chief Ministers, Sahgal's novels present an authentic picture of India before and after independence.

\section{Psychological Transformation}

Nayantara Sahgal's novel Storm in Chandigarh presents a scathing protest against the denial of freedom and individuality to woman. Sahgal's concept of a free woman transcends the limits of economic or social freedom and becomes a mental or emotional attitude. The need for freedom for woman, according to her does no merely mean the defiance of old established conventions; it must also make her aware of herself as an individual and refuse to tolerate should not be seen in the stereotypical passive roles as a sex object or as the one who is fit only to manage home chores and children without any self-identity of her own. For the smooth functioning of family and the society at large, woman needs to be seen as man's equal and honored partner. In her novel, Nayantara Sahgal, "pleads for the new marital morality based on mutual trust, consideration, generosity and absence of pretense, selfishness and self-centeredness."

Nayantara Sahgal's Storm in Chandigarh depicts the suffering of marital friction apart from the political and social ups and downs. It narrates the life of Inder and Saroj. Sahgal pens the suffocating experience of marriage for both the partners. Most importantly, the writer highlights those wrong features in marriage which causes separation. Sahgal, in this novel, deals with marital as well as political crisis. Division in political front and friction in marital relationships are the main themes of the novel. Duality and deceptiveness is prevalent in politics and marriage. In this novel characters come close to each other but without any emotional attachment and sincerity. There is no sensitiveness or loyalty in their relationship; It seems a temporary bond.

In the novel Storm in Chandigarh Sahgal narrates how the attitude of dictatorship destroys harmony of marital status. Marriage which strongly needs love and faith of both the partners, can breakdown also in presence of doubt and frustration. The main protagonist of the novel Saroj has committed mistake before marriage. She has her first sexual encounter with one of her friends before marriage. When Inder came to know that, he started tormenting his wife physically as well as mentally. However Inder himself indulges in an extra marital affair with Mara. Love and satisfaction, is not much prevalent in this affair also. Basically Inder is a character who always denies individuality of women. He considers woman as a parasite; who could survive only with the support of a male figure. Here the writer portraits the pathetic plight of Saroj who tries to show her love and affection towards her husband but in vain.

Throughout their lives, Vishal and Leela remained strangers to each other. He is possessed by a deep sense of guilt for living with her without love and his relationship with Leela abruptly ends due to her death. Vishal's marriage had been a failure. Being a widower, he is deriving satisfaction in a connection with Gauri, a Bengali businessman's wife who finds security in arranged marriage but who needs and establishes a relationship with Dubey which is based only on sex.

Nayantara Sahgal is quite bold in her political approach. She dismantles the age old notions of women being inferior. She is one novelist who is clear in her perception that man-woman relationship should be based on equality, understanding and love. Man-woman relationship without love is prostitution and nothing else. 
In this novel Sahgal has reflected the turmoil in life the political drama. The novel is a proof of her clear thought, vision and maturity. Sahgal is concerned with the sancity of human relationships. She believes that a relationship causes injury and inflicts pain if people withhold (hide) their real selves. Thus in Storm in Chandigarh Nayantara Sahgal demonstrates her keen understanding of individual relationships and her remarkable ability to tell stories that continue to enthrall readers over the years.

Sahgal's fifth novel, A Situation in New Delhi depicts the aftermath of a great popular Prime Minister Shivraj like Jawaharlal Nehru who dominated the political and national scene for a full decade. He was the one who sacrificed his aristocratic family's comforts for the freedom of India. The novel is very much based on history. It is a novel of political dislocation on two levels, on the level of the novelist's own life and on the level of her characters. A Situation in New Delhi focuses the Naxalite movement and student unrest, and above all, the after of Nehru's death. The novel deals with the problems of alienation and frustration of the younger generation of Indians in the context of opportunistic politics in New Delhi. The novel begins with the news of the death of Prime Minister Shivraj, the idealistic and charismatic leader of India. In the novel there is no gap between the private world and the political world; both the worlds are reciprocally treated in which actions and characters come together. The novel is indeed representative of the situation in the whole of India.

\section{Results and Discussion}

A Situation in New Delhi fictionalizes the uncertain state of education and politics in independent India, and was banned during the emergency. It was first published in abroad and then reprinted in India. The novel concentrates on a sense of disintegration giving way to chaos and disorder that engulf the capital.In the novel, Sahgal weaves a narrative around a number of characters: Devi, the sister of the dead Prime Minister Shivraj, who is Nehru in disguise; her son Rishad, a young college-going boy, member of a Naxalite group, who dies in an explosion in a cinema hall; her friend Usman, the Vice-Chancellor of Delhi University, an admirer of Shivraj's policies; and Michael Calvert, an old acquaintance of Shivraj and Devi, who returns to India from England to write his biography. The novel attempts an estimate of the dead leader's personal qualities, his approach to nation building, and his power to influence the lives of people. It builds a contrast between the times before and after Shivraj and begins with the news of the death of Prime Minister Shivraj, the idealist leader of India. Here, the three characters, Shivraj, Usman and Michael, represent the three main religious segments of the Indians, namely, Hindu, Muslim and Christian. The chosen time of action is the late fifties and early sixties when Rishad, Devi's son joins a secretly operating group of student-terrorists. The nineteen year old Rishad gets killed in one of his underground operations and his girlfriend Suvarnapriya becomes the protege of Devi. The novel is the portrayal of the city torn apart by the failure of political leadership and violent student unrest. It would be true to state that the entire book is a tribute of Nehru. Now he is dead. And with his passing away, the country which he had ruled so well begins to fall apart. His intimate followers; Devi, Usman and Michael try to live with Shiraj's ideologies.

Devi, a beautiful lady, a widowed mother of a college student, now in her early fifties, takes up the reins of the officer in her strong hands. She appoints Usman, an old follower of her late brother and her dear friend as the Vice-Chancellor of Delhi University. Usman is forced into accepting the offer as it comes from Devi who needs him to survive in the office with the political ideology they share. Usman is over-burdened with the troubles of unrest and violence in the University campus. He believes that the great ideals should not remain as mere words in the scripture; in fact, the scriptures live only when the people follow them. He condemns the political interference in the academic world and laments for the loss of a leader like Shivraj who had a unique sense of perception, Usman had taken the Vice-Chancellorship to bring about some fundamental changes. He is being pushed into taking back three rusticated students for a rape case. His wife Nadira always blames him for accepting such a post and she proposes to leave the country for some other country if not Pakistan. When the tension reaches its peak Usman advices Devi to resign from the post and from the party. He realizes he futility of his efforts to free the University from political influences. He decides to give up the Vice-Chancellorship. When Shivraj dies, Devi needs Usman body and soul, who makes love to her as she lies on her bed, mourning for her husband Ishwar's bed is still warn when Usman occupies it.

Michael, another important character of the novel, is a renowned English biographer who spent his childhood in India. As a young British boy, he was fascinated by Shivraj. He visits India to pay his homage to the great hero by writing his biography. Both, Usman and Michael have very special relationship with Devi. Both loved her once, and they still love her. She had accepted their love in a very natural way and she still accepts it. Though he is a foreigner, he also has his share of disillusionment in the new political set-up. Michael had observed Devi closely in relation to her brother. Michael remembered Devi as a young girl, who had many admirers but chose only her brother as a companion.

Her commitment to her brother was too strong and firm. Saghal shows a strange relationship between brother and sister. Sahgal has never shown clearly wheher their relationship was sexual or not but they behaved like lovers, or rather as husband and wife. Michael had noticed that 'physical contact' between the brother and sister "was no constant, hand touching, his head bent to hers."

\section{Conclusion}

A Situation in New Delhi, describes a number of woman characters who differ from each other one way or the other. 
Devi seems to exploit the situation as she uses both Usman and Michael and is excessively attached to her brother. She is free and independent. She moves freely among her guests, talking with a gaiety and vitality which is irreversible. People usually fall in love with her. She has passed her life as a shadow of her brother. She does not have any knowledge of official matters. On other hand, Pinky accepts all traditional roles assigned to her. She is a happy girl and very enthusiastic about her marriage and obediently consents to her parent's choice. "Girls like Pinky lived as their mothers and grand mothers had." (P-42). She is considered a voluptuous young version of Veena. (P-36). After the tragic incident of Madhu, she is not been allowed to go out of her house without her mother's permission. But she is very happy with her trousseau saris and thinks herself lucky. While, Veena, Pinky's mother is also an example of traditional Indian woman who cannot think about anything other than her beauty and her household duties. She has never helped Pinky in developing her idendity and individuality. She has only tried to make Pinky a typical traditional woman. She gives a party only because Arvind, her Son-in-law has come to their town "A Son-in-law was sacrosanct. God took second place. Sons-inlaw who had driven their wives" relations to drink, desperation and bankruptcy, somehow vanished blameless into the family's Annals."

Skinny Jaipal is the woman of Sahgal. She has a passion for the act of living and involves herself fully in whatever she undertakes. Nadira another woman character is also not properly adjusted with her husband. Usman desires whole heartedly to share his deepest and innermost thoughts with Nadira, but Nadira remains stubborn, uncompromising and refuses to come out of the fortress around her. The relationship between Usman and
Nadira proves that communication is essential for a harmonious marital relationship. The novel is a finely crafted book, with its neatly structured action in sixteen chapters. Sahgal's analysis of the problems that confront a newly independent and developing country is achieved by focusing her creative attention on the young men and women of free India which is convincing and sensitive.

\section{References}

1. Barry Peter (1995) Beginning Theory. Manchester University Press, New York, USA.

2. Dhawan RK (1991) Indian Women Novelists. Prestige Books, New Delhi, India.

3. Guerin Wilfred L (2005) A Handbook of Critical Approaches to Literature. Oxford University Press, New York, USA.

4. Rao AV, Krishna Nayantara Sahgal (1976) Seshachalam M \& Co.. Madras, India.

5. Roy (1999) Anuradha Feminist Consciousness in Indian Women Writers. Prestige Books, New Delhi, India.

6. Nayantara S (1969) Situation in New Delhi. Delhi: Hind Pocket Books. London: Chatto and Windus, UK.

7. Sahgal Nayantara (1969) A Storm in Chandigarh. Delhi: Hind Pocket Books (originally published London: Chatto and Windus)

8. Sankar G (2016) The Social Realities with Survival Strategies of the Protagonists in Nayantara Shgal's Storm in Chandigarh, American Journal of Educational Research and Reviews (AJERR) 1(1).

9. Gupta GS (1987) Balarama Studies in Indian Fiction in English. Gulbarga: Jiwe Publications, India.

\section{Your next submission with Juniper Publishers will reach you the below assets}

- Quality Editorial service

- Swift Peer Review

- Reprints availability

- E-prints Service

- Manuscript Podcast for convenient understanding

- Global attainment for your research

- Manuscript accessibility in different formats

( Pdf, E-pub, Full Text, Audio)

- Unceasing customer service

Track the below URL for one-step submission https://juniperpublishers.com/online-submission.php 